\title{
Behavioural Aspects of Postgraduate Students in Using Electronic Information Resources at the Library Eastern University, Sri Lanka
}

\author{
M. Jayakananthan ${ }^{1}$ \\ W. J. Jeyaraj ${ }^{2}$
}

\begin{abstract}
The introduction of computer technology in university libraries has made possible the use of information resources via the Internet or Intranet. Since the poor usage of digital resources by students as well as the staff of universities has strained these innovative efforts towards the next information era, there was a need to carry out research to examine the behavior in utilizing electronic information resources in higher educational institutions. The main objective of this study is to examine the behavioral intention to utilize electronic information resources by postgraduate students at the Eastern University, Sri Lanka (EUSL), applying the Unified Theory of Acceptance and Use of Technology (UTAUT) model. The study was tested with a conceptual model using 208 postgraduate students. The study revealed that the facilitating-conditions and effort expectancy are highly significant to students' behavioral intention to use electronic information resources at the library. Students' computer experience moderated the relationship between facilitating-conditions and intention to use. The intention-to-use behavior highly impacts on students' usage of electronic information resources. The developed model will assist other researchers to understand the students' behavioural intention and influencing factors in respect to introducing new innovative technologies in libraries and it could be used by other higher education institutions to make decisions related to the investment in the modern library systems. Hence, this study recommends further researches to be covered in all the Sri Lankan Universities in order to generalize the results and findings.
\end{abstract}

Keywords: Electronic Information Resources, UTAUT, Technology Acceptance

\section{Introduction}

Information Technology (IT) has transformed the learning activities within higher educational institutions. The learning method is no longer limited to the formal setting, that is, classrooms and face-to-face learning, since all the learning materials are now available digitally and allow the students to access them anytime, from anywhere. As a result, the higher educational institutions adopt mechanisms such as an electronic library or digital library that ensures the easy electronic accessibility of study materials like books, journals, and other resources. In a study done by Awwad \& Al-Majali (2015), stated that web-based electronic information sources have

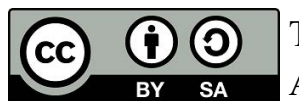

This work is licensed under a Creative Commons Attribution- Share Alike 4.0 International License.

\footnotetext{
${ }^{1}$ Systems Analyst. Email: jeyakananthanm@esn.ac.lk

${ }^{2}$ Acting Librarian, Eastern University, Sri Lanka, Email: jeyarajwj@esn.ac.lk
} 
recently developed most powerful research support tools and continue to increase in importance for the academic community. However, it was found that there is low utilization of web-based electronic resources in Sri Lankan university students (Millawithanachchi \& Jayasundara, 2012). In a recent study by Samaradiwakara (2014) reports that technology is of little value unless it is used, how people accept and use technology may have salient theoretical and practical implications. EUSL library contains books, periodicals, and non-printed digital materials in different fields such as Social Sciences, Humanities, Education, Management, Sciences and Technology. Further, the library provides valuable services through fully automated KOHA Integrated Library Management Systems (ILMS) and Digital Repository (IR) with separate electronic information resource unit.

The library web portal (http://www.lib.esn.ac.lk) provides the information to students and faculty members and it consists of all the relevant details about the resources and services. Apart from the web portal, CD/DVDs and multimedia devices are available in the electronic resource unit. The Online Public Access Catalogue (OPAC) of the library provides web-based access to books, periodicals, and provides basic and advanced searching facilities. Institutional Repository (IR) has multiple collections of research publications by researchers and students of the Eastern University, Sri Lanka. The Library has wide access to several online full-text electronic databases through the Consortium of University Grants Commission (UGC) such as EMERALD and OXFORD. In addition to that, the library offers several other services, such as Inter-Library Loan (ILL), research support services, ICT lab facilities, career guidance and services for differently able students. The following Table 1 presents available electronic information resources and services at the EUSL library. The current research consists of e-Journals, Databases and Theses Collection are the main categories of electronic information resources in examining the postgraduate students' behavior.

Table 1 : Available Electronic Information Resources and Services

\begin{tabular}{|c|c|}
\hline Resources & Accessible Status \\
\hline $\begin{array}{l}\text { Online Public Access Catalogue } \\
\text { (OPAC) }\end{array}$ & www.opac.lib.esn.ac.lk (90000 Books) \\
\hline Digital Theses Collection & www.digital.lib.esn.ac.lk (2000 Records) \\
\hline Digital Rare Collection & LAN Only (4000 Records) \\
\hline e-Journals and Databases & $\begin{array}{l}\text { Through UGC Consortia and other Open } \\
\text { Access Directories }\end{array}$ \\
\hline DVD/ CD Collection & 1200 Collection \\
\hline
\end{tabular}

\section{Statement of the Problem}

The modern innovative technologies have been introduced in university libraries; as a result, electronic web-based materials have popular among university communities. University Grants Commission of Sri Lanka has spent a considerable amount of money to subscribe for e-resources to provide access to all Sri Lankan university 
library users. However, it is observed that such resources are not enthusiastically used by the post graduate students. Since the nature of electronic web-based information retrieval is quite new and a unique phenomenon to the EUSL library users, it is crucial to investigate the factors that could influence the use of electronic information resources. Even though there are different factors that influence the students' behavior to use electronic information resources these factors may not be properly identified in the local context. Therefore, there is a need to carry out a research study to examine factors that influence the students' behavioral intention to use electronic information resources from emerging technology acceptance models.

\section{Research Objectives}

The main objective is to examine the postgraduate students' behavioral intention to utilize electronic information resources provided by the library, Eastern University, Sri Lanka.

\section{Specific Research Objectives}

In order to achieve the main objective of the research, the research has set out the following specific objectives:

1) To identify what types of electronic information resources are used by postgraduate students.

2) To identify the factors that influence the postgraduate students' behavioral intention to use electronic information resources.

3) To develop a conceptual framework for students' behavioral intention to use electronic information resources.

\section{Literature Review}

The adoption of information technology in libraries has changed the way they acquire, store, and disseminate information to their users and way the individual patrons require and use information (Rehman, 2012). In a study by Dilroshan (1995) reveals that electronic libraries reduce the danger of repeated manual efforts in library routine and library users can access information irrespective of time and location of the information source. Also, stated that the cost and lack of enough training are the main problems faced by the library professionals to use Information Technology in Libraries.

New library services include digital library, institutional documents, Journals, ebooks, dissertations and theses, course materials are some of the important sources of information that are now available in electronic format (Quadri, 2012). In another study, Peris (2012) emphasized that most accessible resources were web pages and email, while the lowest accessible resource was the in-house library databases. The results further said the half of the respondents use electronic information resources daily while others use it weekly, monthly, fortnightly, quarterly and once a six-month period.

The study carried by Karunarathna (2015) and found that the majority of the respondents have used a few electronic resources such as e-books, e-chapters, e- 
indexes, e-abstracts. Most of the respondents never used some electronic resources such as electronic thesis and dissertations. The study further claims that lack of awareness and lack of skills are the barriers to access electronic resources. He et al. (2012) conducted a comparative study between two universities in the USA and China, the university students would have different views on the importance of internet-based information sources when they undertake various academic tasks, and their opinions will be affected by the country/culture factor.

A study conducted by Wu \& Chen (2012) in Taiwan and investigated how graduate students perceive, use, and manage electronic resources. The study clearly noted that graduate students are frequent users of electronic information resources, and they perceive that the resources are important to their studies. Further, noted that the library could support most documents they need in digital format. Another study conducted by Kaur \& Verma (2009) at IIT, Delhi and observe that the main users of library electronic resources are postgraduates, research scholars and faculty members. The maximum numbers of users prefer to use both the formats of the documents, i.e. print as well as electronic information. The electronic journals are generally used twothird times a week by those who responded to the survey. They access the information more from their respective department, hostel and Computer Centre than they do the library. Margaret \& Mabawonku (2013) opined that there is an increase in the provision of electronic resources in Nigerian university libraries, yet studies have revealed that there is low use of the resources by students and this is due to lack of information retrieval skills. Further, the survey data showed that students are lacked requisite skills for the use of electronic resources. The study about e-Journals at Indian Institute of Technology, Delhi, India, the Kaur \& Verma (2009) observe the undergraduates, who are not the main users, are also trying their hand to find out whether the information in these electronic resources is useful to them or not. The main users of these electronic resources are postgraduates, research scholars and faculty.

Punchihewa (2008) explores the usage of online databases and user perceptions in Moratuwa University as low usage level was observed for the online journals compared to print journals. Also, the study stated that academic members and the postgraduate students had higher online resource usage than the undergraduate students. The major difficulties examined within the study included lack of computer and Internet facilities, lack of awareness of electronic resources provided by the library, ineffective communication channels, inefficient support of the library and irrelevancy of articles in the provided databases. In the University of Colombo, lack of computers, low internet connection speed, less reliable network and lack of training and awareness were among common problems in electronic learning functionalities. Lack of funds, staff development, user training, promotion, technical issues, and faculty-library collaboration are other obstacles to electronic learning (Millawithanachchi, 2009).

In a study about the use of electronic resources in Kenya Ingutia-oyieke \& Dick, (n.d.) stated that academic libraries have identified several categories of barriers:; 
Inadequate infrastructure networks such as intranets and the internet; lack of nativelanguage content and software; power outages; and restricted access to ICT facilities; not knowing what information is needed or available; not knowing where to look, meaning that they may have a question or problem but do not know where to turn for help; not knowing what sources of information exist; many are pleasantly surprised when guided to existing resources by their librarians; lacking the confidence or technical skills required to use computers in the case of online information searching; and becoming discouraged by long delays when trying to access information resources, especially if the network connection is slow. Egberongbe (2011) observes that the uses of electronic resources are very common among the lecturers and research scholars of the University of Lagos. It also observed that the majority of teachers and research scholars are dependent on electronic resources to get desired and relevant information. It was however, revealed that practical uses of electronic resources are not up to the worth in comparison to investments made in acquiring these resources. Moreover, infrastructure and training programmes are essential for better use of electronic resources campus-wide.

According to Millawithanachchi (2009), Technology Acceptance Model (TAM) and Theory of Reasoned Action (TRA) are very important conceptual theories to investigate the Critical Success Factors on e-resource based learning research. Wu et al. (2007) used the UTAUT to explore the behavior of $3 \mathrm{G}$ mobile communication users in Taiwan. It was found that performance expectancy and facilitating conditions have had a significant influence on behavioral intention to use $3 \mathrm{G}$ mobile communications in Taiwan. Tibenderana (2008) applied the UTAUT model to study the use of hybrid library services in Ugandan universities; the findings validated the model as an efficient and robust tool for technology acceptance studies.

With regard to the use of electronic information resources, the literature review has clearly shown that researchers and postgraduates are increasingly using various electronic resources to meet their academic and personal information needs. Therefore, it clearly observes that the function of library services has not changed. It still supports education, whether it's traditional, computer-based or web-based learning. So, libraries should continue to adopt the developments in technology and support teaching and learning by providing full access to all possible information resources to all user communities.

\section{Theoretical Foundation and Conceptual Framework}

Several intention-based theories and models have been proposed and empirically tested over the last decade in understanding user adoption and usage of information technology innovations. For example, Fishbein and Ajzen, in 1975 proposed the theory of Reasoned Action (TRA), Davis and his colleagues, in 1989 introduced Technology Acceptance Model (TAM), Ajzen in 1991 proposed the Theory of Planned Behavior and Roger, in 1995 tested the Innovation Diffusion Theory. These theories have been applied to a variety of information technologies in different contexts and populations (Li, 2010). In a comparison study (Samaradiwakara, 2014) clearly states that these theories / models have been expansively applied in a vast 
array of research studies in technology contexts and other various areas of academic interest and they have further proven their enhanced applicability in modeling technology acceptance in different contextual settings. The study further compared fourteen theories / models and emphasized that the UTAUT seems to be an improved theory that could provide a useful tool to assess the likelihood of success for technology acceptance studies. Venkatesh et al. (2003) and Kriponant (2007) have also compared nine models based on literature. Therefore, the model comparison results conclude as a more pragmatic approach and they have determined the individual model's ability to explain behavioral intention (based on the explained variance $\mathrm{R}^{2}$ ). Table 2 presents a summary of technology acceptance theories/models compared in terms of their key constructs, moderators and the explained variance.

Table 2: Technology acceptance theories/models comparison

\begin{tabular}{|c|c|c|c|}
\hline Theory/Model & $\begin{array}{ll}\text { Constructs } & \text { (Independent } \\
\text { variables) } & \end{array}$ & Moderators & $\begin{array}{l}\text { Explained } \\
\text { variance } \\
\left(\mathrm{R}^{2}\right)\end{array}$ \\
\hline $\begin{array}{l}\text { Theory of Reasoned } \\
\text { Action (TRA) }\end{array}$ & $\begin{array}{l}\text { 1. Attitude toward } \\
\text { behavior } \\
\text { 2. Subjective norm }\end{array}$ & $\begin{array}{l}\text { 1.Experience } \\
\text { 2.Voluntariness }\end{array}$ & 0.36 \\
\hline $\begin{array}{l}\text { Technology } \\
\text { Acceptance Model } 2 \\
\text { (TAM2) }\end{array}$ & $\begin{array}{l}\text { 1. Perceived usefulness } \\
\text { 2. Perceived ease of use } \\
\text { 3. Subjective norm }\end{array}$ & $\begin{array}{l}\text { 1.Experience } \\
\text { 2. Voluntariness }\end{array}$ & 0.53 \\
\hline $\begin{array}{l}\text { Motivation Model } \\
(\mathrm{MM})\end{array}$ & $\begin{array}{l}\text { 1. Extrinsic motivation } \\
\text { 2. Intrinsic motivation }\end{array}$ & None & 0.38 \\
\hline $\begin{array}{l}\text { Decomposed Theory } \\
\text { of Planned Behavior } \\
\text { (DTPB) }\end{array}$ & $\begin{array}{l}\text { 1. Attitude toward } \\
\text { behavior } \\
\text { 2. Subjective norm } \\
\text { 3. Perceived behavioral } \\
\text { control }\end{array}$ & $\begin{array}{l}\text { 1.Experience } \\
\text { 2. Voluntariness }\end{array}$ & 0.36 \\
\hline $\begin{array}{l}\text { Combined } \\
\text { Technology } \\
\text { Acceptance Model } \\
\text { and Theory of } \\
\text { Planned Behavior (C- } \\
\text { TAM-TPB) }\end{array}$ & $\begin{array}{l}\text { 1. Attitude toward } \\
\text { behavior } \\
\text { 2. Subjective norm } \\
\text { 3. Perceived behavioral } \\
\text { control } \\
\text { 4. Perceived usefulness }\end{array}$ & 1. Experience & 0.39 \\
\hline $\begin{array}{l}\text { Model of PC } \\
\text { Utilization (MPCU) }\end{array}$ & $\begin{array}{l}\text { 1. Job fit } \\
\text { 2. Complexity } \\
\text { 3. Long term } \\
\text { consequences } \\
\text { 4. Affect towards use } \\
\text { 5. Social factors } \\
\text { 6. Facilitating conditions }\end{array}$ & 1. Experience & 0.47 \\
\hline $\begin{array}{l}\text { Innovation Diffusion } \\
\text { Theory (IDT) }\end{array}$ & $\begin{array}{l}\text { 1. Relative advantage } \\
\text { 2. Ease of use } \\
\text { 3. Result demonstrability } \\
\text { 4. Triability }\end{array}$ & 1. Experience & 0.40 \\
\hline
\end{tabular}




\begin{tabular}{llll}
\hline & 5. Visibility & & \\
& 6. Image & & \\
& 7. Compatibility & & \\
& 8. Voluntariness of use & & \\
Social Cognitive & $\begin{array}{l}\text { 1. Outcome expectation } \\
\text { 2. Self-efficacy }\end{array}$ & None & \\
Theory (SCT) & 3. Affect & \\
& 4. Anxiety & & \\
Unified Theory of & 1. Performance & 1. Gender & 0.69 \\
Acceptance and Use & expectancy & 2. Age & \\
of Technology & 2. Effort expectancy & 3.Experience \\
(UTAUT) & 3. Social influence & 4.Voluntariness & \\
& 4. Facilitating conditions & & \\
\hline
\end{tabular}

Source: (Venkateshet al. 2003; Kripanont 2007).

According to the reviewed literature and the comparison of Table 2, explanatory power of technology usage intention in terms of variance has ranged from 0.36 lowest to 0.69 (UTAUT) highest. Therefore, UTAUT model will provide a solid base to explain why users accept or reject technology from a specific perspective and it has much potential in enhancing the understanding of technology acceptance. By focusing on the adoption and examining the students' behavior towards the use of electronic information resources, which is the intended research study, the Unified Theory of Acceptance and Use of Information Technology (UTAUT) was selected as the most suitable theory for the study. According to the Venkatesh et al. (2003), there are four main constructs available in UTAUT which were defined as follows:

1. Performance Expectancy - the degree to which the user believes that using electronic information resources will enhance his/her job performance;

2. Effort Expectancy -the perceived level of ease of electronic information resources usage.

3. Social Influences - the degree to which the user perceived that using the electronic information resources might be due to the influence or believes of individuals around him/her.

4. Facilitating Conditions - the degree to which the users believe that technological infrastructure exists to support the electronic information resources usage.

In order to carry out the research, the above four constructs are adapted to the conceptual model and moderator variables such as gender, age and experience are also included. Voluntariness removed from the conceptual model as all population belongs to the same university and access similar resources through library portal. One more moderating variable "experience in computer usage" was added to the model which derived by the authors of this paper from 'experience' of Venkatesh et al. (2003). 


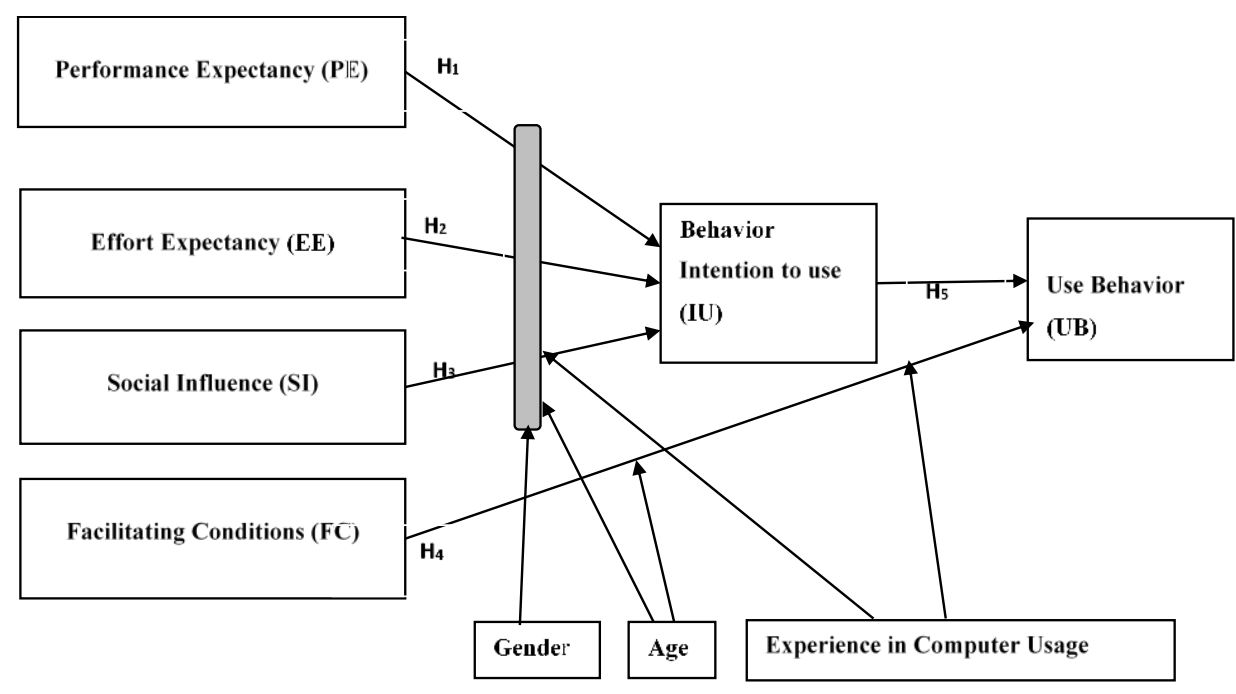

Figure 1 : The Research Conceptual Model (Adapted from Venkatesh et al. 2003)

In line with the research model Figure 1 and the literature in technology acceptance areas, the study has developed the following hypotheses.

$\mathbf{H}_{1}$ : Performance expectancy positively impacts on students' intention to use electronic information resources.

$\mathbf{H}_{2}$ : Effort Expectancy positively impacts on students' intention to use electronic information resources.

$\mathbf{H}_{3}$ : Social Influence positively impacts students' intention to use electronic information resources.

H4: Facilitating Conditions positively impact students' behavior towards electronic information resource usage.

H5: Intention to use positively impact students' behavior towards electronic information resource usage.

Moderating factors positively impact on four UTAUT constructs towards intention to use electronic information resource.

$\mathrm{H}_{\mathrm{a}}$ : The influence of PE, EE, SI and FC are positively moderated by Age towards an intention to use.

$\mathrm{H}_{\mathrm{b}}$ : The influence of PE, EE, SI and FC are positively moderated by Gender towards an intention to use.

$\mathrm{H}_{\mathrm{c}}$ : The influence of $\mathrm{PE}, \mathrm{EE}, \mathrm{SI}$ and $\mathrm{FC}$ are positively moderated by Computer Experience towards an intention to use.

\section{Research Design and Methods}

A sample of the population comprises of two hundred and twenty-four (224) postgraduate students (Postgraduate Diploma, Masters and $\mathrm{PhD}$ ) from four faculties in the University and all members of the population were given an opportunity to participate in the study. Postgraduate students are purposely chosen as they actively seek information and resources for their day to day study and research activities. A questionnaire was developed and distributed among the students at their respective 
faculty locations. The research instrument consisted of 31 close-ended questions. The questions were categorized into three sections (A-C) depending on their relevance and their relationship. Students' gender, age and the level of experience and background of the respondents' electronic information resource usage are categorized in the Section A. Questions in section B were developed using the attribute of the 4 constructs and intention to use behavior questions from the UTAUT. Five-point scale (1-Strongly disagree, 2- Disagree, 3-Uncertain, 4-Agree, 5-Strongly Agree) was used to rate the identified factors in a hierarchical form. The last section which is section $\mathrm{C}$ focused on the opinions of the participants' usage behavior of the electronic information resources. Collected data were analyzed using SPSS version 21 with AMOS. The analyze techniques such as descriptive statistics, Chi-square test, Structural Equation Model and Multi-group moderation were used to interpret the results of the study.

\section{Results and Discussion}

The questionnaires were administered to the whole population (224) and by the end of the data collection exercise, 208 questionnaires had been filled and returned, representing $93 \%$ of the total administered questionnaires.

\section{Validity and Reliability}

According to the model presented by Venkatesh et al., (2003), this study adopted a conceptual model with the aim of understanding the students' intention to use and acceptance of e-resources. This model was already tested and validated by the researchers where its strength was $70 \%$ which proves that it is more effective than all the other models that were adopted in the past (Wu \& Yang, 2007).This study adopted the quantitative method to test the reliability of the UTAUT model which was tested through Cronbach's Alpha coefficient. Kalema \& Kekwaletswe (2011) indicated that reliability constructs must be at least 0.7 and this was proven by Venkatesh et al. (2003). Table 1 below shows the reliability and validity of the constructs.

Table 3: Cronbach's Alpha $(\mathrm{N}=\mathbf{2 0 8})$ values of Constructs

\begin{tabular}{lcc}
\hline \multicolumn{1}{c}{ Constructs } & Cronbach's Alpha & No. of Items \\
\hline Performance Expectancy (PE) & 0.771 & 4 \\
Effort Expectancy (EE) & 0.774 & 4 \\
Social Influence (SI) & 0.806 & 4 \\
Facilitating Conditions (FC) & 0.720 & 3 \\
Behavior Intention to Use (IU) & 0.726 & 3 \\
Use Behavior (UB) & 0.787 & 3 \\
\hline
\end{tabular}

As outlined in the above Table 3 the reliability of all the proposed conceptual model constructs was investigated with Cronbach Alpha $(\alpha)$. The performance expectancy (PE), effort expectancy (EE), social influence (SI), and facilitating conditions (FC) are achieved above the recommended Cronbach Alpha $(\alpha)$ of 0.7 . In addition to that Intention to Use (IU) and Use Behavior (UB) also fit the recommended Cronbach 
Alpha $(\alpha)$. This result interprets that the items in the construct are reliable for further analysis.

\section{Demographic Characteristics of Respondents}

Table 4 clearly indicates that $91.2 \%$ of the respondents were aged 25-35 and were followed by the age range of $36-50$ years which is of $8.8 \%$. This shows that most of them were already considered as young adults. The results show that the distribution of male \& female was proportionate. The 52\% male respondents and the $48 \%$ female respondents were a total of 108 and 100 respectively. Based on the figure, the dominant gender among the respondents was male. This shows that there is a majority of males who have an interest in participating in research studies at the EUSL. As indicated in Table 4, among the respondents 57\% were pursuing a Postgraduate Diploma whilst $40 \%$ read Master's Degree. There is a fewer percentage of respondents participating in the Master of Philosophy and Doctor of Philosophy. The respondents' study programme are categorized under five main subjects such as Arts and Culture, Development Studies, Agriculture Science and Science Education. Among the respondents $99 \%$ of postgraduate students have computer experience for more than two years and a smaller number of students have below two years of computer experience.

Table 4: Demographics Information of Postgraduates

\begin{tabular}{llcc}
\hline \multicolumn{1}{c}{ Demographic Factor } & \multicolumn{1}{c}{ Group } & Frequency & $\%$ \\
\hline \multirow{2}{*}{ Gender } & Male & 112 & 53.8 \\
Age & Female & 96 & 46.2 \\
& $25-35$ & 191 & 91.2 \\
\multirow{3}{*}{ Degree Level } & $36-50$ & 17 & 8.8 \\
& Postgraduate Diploma & 118 & 56.7 \\
& Master Degree & 84 & 40.4 \\
& Master of Philosophy & 4 & 1.9 \\
& Doctor of Philosophy & 2 & 1 \\
Program of Study & Arts and Culture & 76 & 36.5 \\
& Business Studies & 64 & 30.7 \\
& Development Studies & 44 & 21.2 \\
Experience in & Agriculture Science & 13 & 6.3 \\
Computer Usability & Science Education & 11 & 5.3 \\
& 1-2 Years & 2 & 1 \\
& More than 2 years & 206 & 99 \\
\hline
\end{tabular}

\section{Background of the Electronic Information Resources Usage}

Analysis of students' background in electronic information usage indicated that $68 \%$ students had their own laptop/desktop. This information reveals that the majority of students have computer facilities and had average ICT knowledge towards access to electronic information resources. Most of the students had Internet access and most of them used library ICT unit for accessing electronic information resources. Among electronic information resources; e-journals, online databases, and theses collections are mainly used. 
Table 5: Background of the Electronic Information Resources usage

\begin{tabular}{lll}
\hline Factors & Group & $\%$ \\
\hline Own Desktop/Laptop & Yes & 68 \\
& No & 32 \\
ICT & Poor & 24 \\
knowledge & Average & 42 \\
\multirow{2}{*}{ Internet facility availability } & High & 34 \\
& Yes & 78 \\
Place/way of accessing electronic & No & 22 \\
information resources & ICT Unit & 21 \\
& Library ICT Unit & 42 \\
Mostly used electronic information & Open Wi-Fi & 37 \\
resources & E-journals & 36 \\
& Online Databases & 42 \\
& Theses Collection & 22 \\
\hline
\end{tabular}

Evaluation of validity and the reliability of the Model

The proposed research model consists of six latent variables including four exogenous (PE, EE, SI, and FC) and two endogenous (IU, UB) constructs. Tables $6 \& 7$ presents the Squared Multiple Correlations (SMC) values for observed variables. According to the reliability values $(\mathrm{SMC}<0.5)$ there are six items (FC1, SI1, EE1, PE1, UB1 \& IU3) were removed from the model.

Table 6: SMC for Exogenous Variables

\begin{tabular}{cc}
\hline Constructs & SMC Estimate \\
\hline FC3 & .522 \\
FC2 & .779 \\
FC1 & .485 \\
SI4 & .684 \\
SI3 & .513 \\
SI2 & .765 \\
SI1 & .442 \\
EE4 & .550 \\
EE3 & .552 \\
EE2 & .536 \\
EE1 & .118 \\
PE4 & .531 \\
PE3 & .645 \\
PE2 & .774 \\
PE1 & .089 \\
\hline
\end{tabular}


Table 7: SMC for Endogenous Variable

\begin{tabular}{cc}
\hline Dependent Variables & SMC Estimate \\
\hline UB3 & .561 \\
UB2 & .692 \\
UB1 & .423 \\
IU3 & .348 \\
IU2 & .517 \\
IU1 & .559 \\
\hline
\end{tabular}

Correlation values of the exogenous and endogenous variables are decided whether there any discriminant validity among the constructs. Table 8 shows that there are no higher correlations among the exogenous and endogenous variables. It shows that constructs are under discriminant validity.

Table 8: Correlation of Exogenous and Endogenous Variables

\begin{tabular}{lc}
\hline Exogenous variables & Correlation Estimate \\
\hline PE<-->EE & -.021 \\
EE<-->SI & .010 \\
FC<-->SI & .528 \\
PE<-->SI & -.685 \\
FC<-->PE & -.244 \\
FC<-->EE & .500 \\
Exogenous variables & \\
UB <--> IU & .268 \\
\end{tabular}

\section{The Measurement Model}

The research model further revised and re-run with AMOS for the best fit. The Figure 2 shows that model yielded with the measures, $\chi 2$ (chi-square) value was 224.555, degrees of freedom $=78, \mathrm{p}$-value $=0.000, \mathrm{CMIN} / \mathrm{DF}=2.161, \mathrm{RMSEA}=.126$, $\mathrm{TLI}=.896, \mathrm{CFI}=.839$ and $\mathrm{NFI}=.891$. 


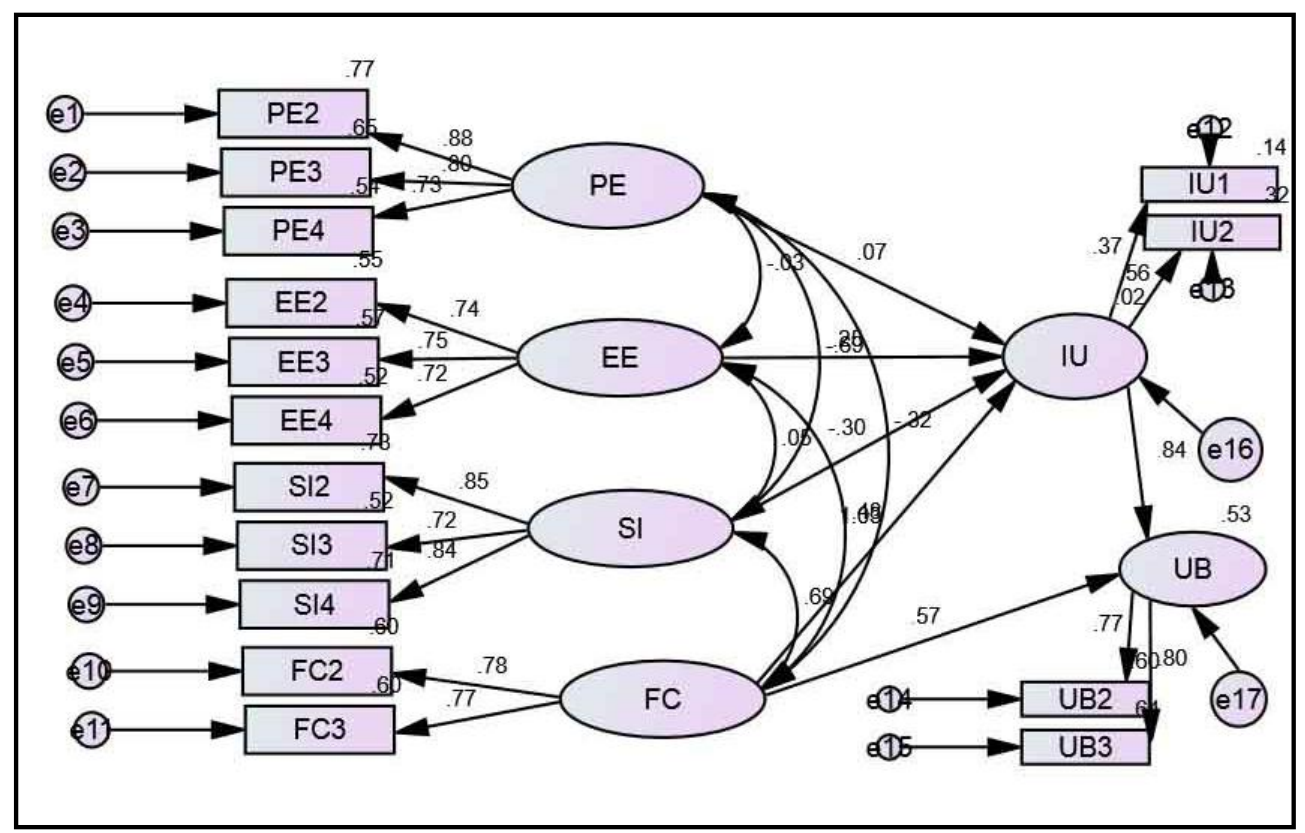

Figure 2: Modified Model with Standardized Estimates

The indices such as Chi-square/df $<3$, GFI $>0.9$, AGFI $>0.9$, CFI $>0.9$, RMSEA $<0.08$ values show a good model fit (Hair et al., 2010). According to the above statistical results and the measures it is clear that the model fit is not that much attained. However, this was treated to be fit as almost all indices are approximate to the standard values. After the model trimming, the final model illustrated by the Figure 3 describes the electronic information resources use behavior of the postgraduate students in the university. The final model includes only significant relationships and model confirms that $45 \%$ of the variance of user behavior is predicted by the independent variables and $24 \%$ of the variance of intention to use predicted by the independent variables and Intention-to-use behavior. The findings of this study revealed that there was a new significant relationship between Facilitating Conditions (FC) and Intention to Use (IU).

As indicated in Table 9, the modified model results show that $\mathbf{H}_{\mathbf{1}}$ is rejected $(\mathrm{p}>0.05)$. The results also found that performance expectancy was not significantly and positively related to the students' intention to use electronic information resources. Thus, the result implies that postgraduate students of EUSL who have less level of performance expectancy to use the electronic information resources. Further, $\mathbf{H}_{2}$ is accepted $(\mathrm{p}<0.05)$. The result shows that Effort Expectancy positively impacts on students' intention to use electronic information resources. This implies that postgraduate students who have more effort to use of electronic information resources would have high intention to use electronic information resources. The hypothesis $\mathbf{H}_{3}$ is not supported $(p>0.05)$. The results clearly indicate that social influence has no effect on intention to use electronic information resources. This can be interpreted that the postgraduate students' social circle i.e. peers, friends, staff etc. have no 
influence on them to use electronic information resources. Hypothesis $\mathbf{H}_{\mathbf{4}}$ is accepted $(\mathrm{p}<0.05)$. The results show that facilitating conditions have positive effect on intention to use electronic information resources. It means EUSL library has resources and supporting conditions to use electronic information resources. Postgraduate students feel that they have requisite knowledge for using and integrating electronic information resources in their academic activities. Also, they are confident about if they obtain any support from EUSL library for using electronic information resources or not. Another hypothesis $\mathbf{H}_{5}$ is supported $\mathrm{p}<0.05$. This implies Intention to use positively impact students' behavior towards electronic information resource usage.

Table 9: Regression weights of the modified model

\begin{tabular}{ccccc}
\hline & Estimate & S.E. & C.R. & P \\
\hline IU<---PE & -.029 & .030 & .972 & .331 \\
IU<---EE & .134 & .053 & 2.530 & .011 \\
IU<---SI & -.112 & .058 & -1.924 & .054 \\
IU<---FC & .449 & .104 & 4.307 & $* * *$ \\
UB<---FC & .486 & .476 & -3.121 & .002 \\
UB<---IU & .990 & 1.280 & 3.117 & .002 \\
\hline
\end{tabular}

Table 10 shows that the covariance between the constructs in the model. PE, EE, and SI were not statically correlated among them.

Table 10: Covariance between the constructs in the modified model

\begin{tabular}{lrrrr}
\hline & Estimate & S.E. & C.R. & P \\
\hline PE<-->EE & -.019 & .057 & .340 & .734 \\
EE<-->SI & .037 & .061 & .600 & .549 \\
FC<-->SI & .605 & .094 & 6.419 & $* * *$ \\
PE<-->SI & .653 & .095 & 6.902 & $* * *$ \\
FC<-->PE & .259 & .074 & 3.508 & $* * *$ \\
FC<-->EE & .298 & .064 & 4.623 & $* * *$ \\
\hline
\end{tabular}




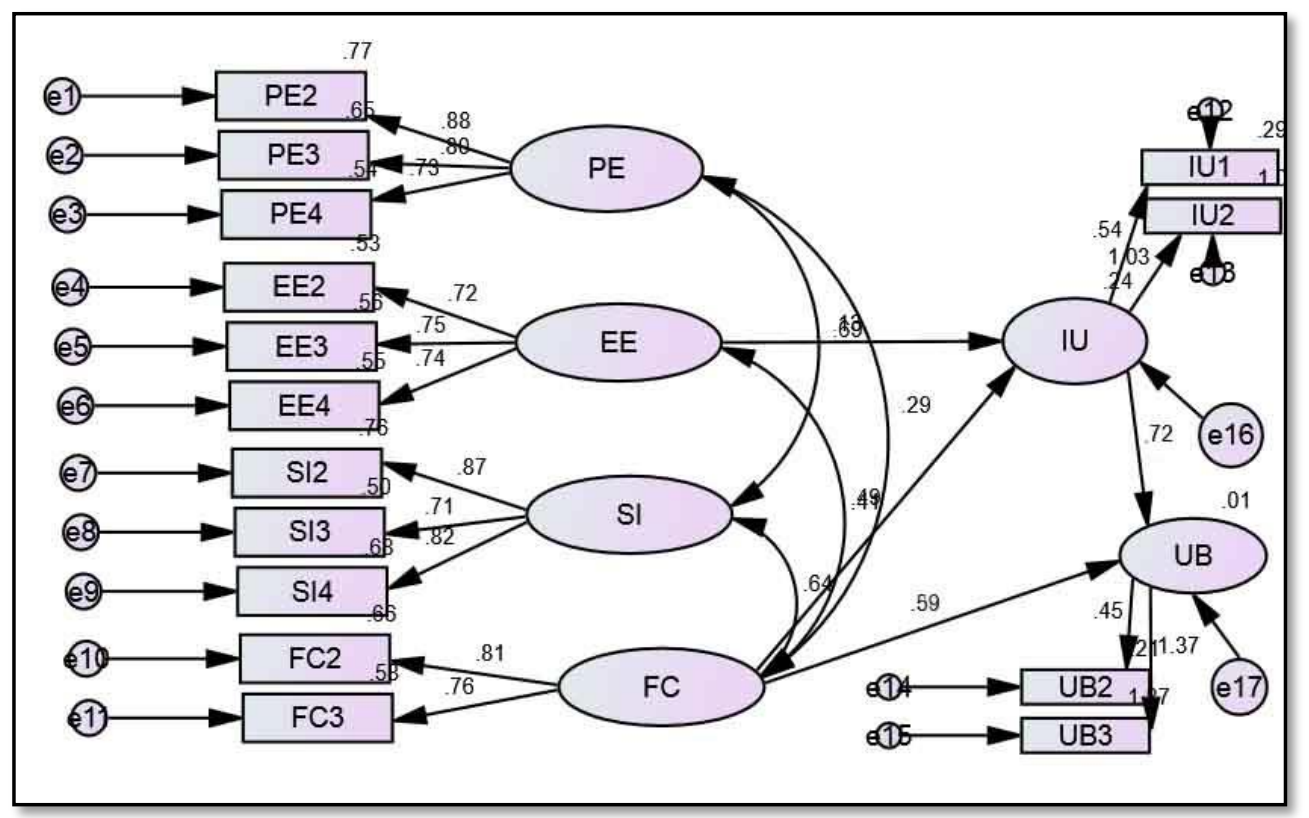

Figure 3: Final Modified Model

\section{The Measurement of Moderating Variable}

Multi-group moderation tests were conducted using the full model. To test the moderation hypotheses full model performed by Critical Ratios for Differences to the variables (Age, Gender and Computer Experience). From these critical ratios Z-Score values was used to determine the significance of the difference. Calculated value is to be greater than 1.96 (absolute value of 1.96) for the difference between paths and $\mathrm{p}<0.05$ to be statistically significant. Table 11 represents the summery of the multi group moderation analysis results. According to the results age and gender were not significantly different between any of the determinants and intention to use. But Computer experience is a stronger determinant of facilitating condition towards intention to use electronic information resources. Therefore, moderating hypothesis $\mathrm{H}_{\mathrm{a}}$ and $\mathrm{H}_{\mathrm{b}}$ are rejected and $\mathrm{H}_{\mathrm{c}}$ is accepted.

Table 11: Multi Group Moderation (Z-Score)

\begin{tabular}{lrrr}
\hline & \multicolumn{1}{c}{ Age } & \multicolumn{1}{c}{ Gender } & Computer Experience \\
\hline IU<---PE & .829 & .331 & .651 \\
IU<---EE & .934 & 1.411 & .721 \\
IU<---SI & -.912 & .954 & .054 \\
IU<---FC & .449 & .651 & 2.631 \\
UB<---FC & -1.186 & 1.002 & .832 \\
\hline
\end{tabular}




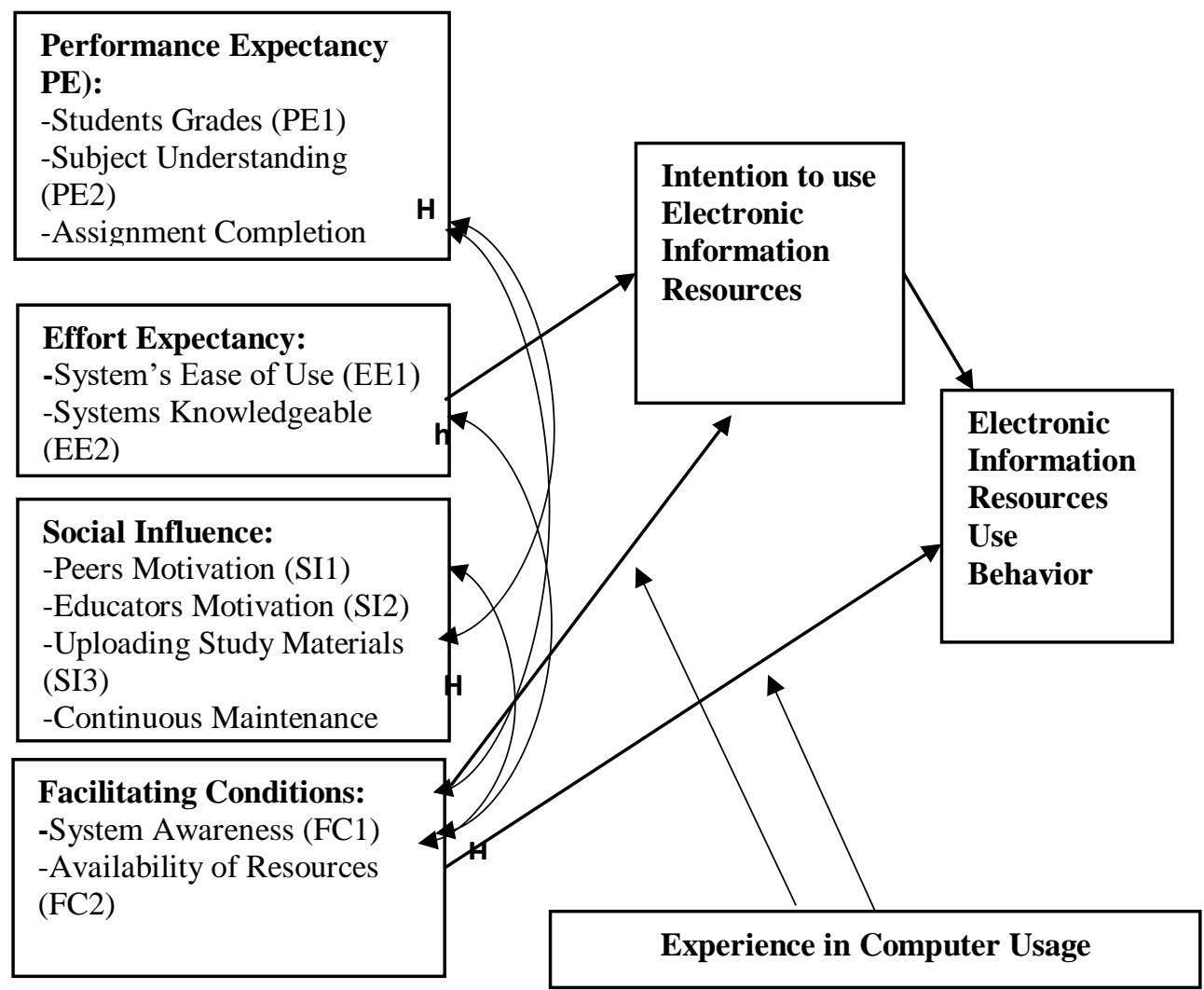

Figure 4: Final Model

The final model describes the current postgraduate students' intention to use behavior towards electronic information resources usage. The model was acceptable fit through the following measures: Comparative Fit Index $(\mathrm{CFI})=0.997$, Root Mean Square of Error Approximation $($ RMSEA $)=0.081$, Adjusted Goodness of Fit Index $($ AGFI $)=$ 0.91 and Goodness of Fit Index $(\mathrm{GFI})=0.98$. In the model effort expectancy and facilitating conditions are the factors which describe the intention to use electronic information resources. Further they explain $24 \%$ of the variance. Computer experience has a significant moderating effect on the relationship between facilitating conditions and intention to use behavior. The usage behavior described by facilitating conditions and intention to use. Performance expectancy and Social Influence negatively influence the intention to use.

\section{SUMMARY AND CONCLUSIONS Effort Expectancy}

The research result support to confirm that the effort expectancy (EE) determinants significantly impact on the intention to use (IU) electronic information resources. Consequently, the ease of electronic information resources and navigation, effort 
spent to use electronic information resources are the major determinants influencing students' intention to use electronic information resources.

\section{Facilitating Condition}

It was measured by the perception of accessing the required resources, the necessary knowledge and technical support needed to use electronic information resources. The study results were supported the facilitating conditions positively have a significant relationship to the students' intentions to use electronic information resources.

\section{Intention to use and usage behavior}

The study results confirm that the student's intention to use behavior positive impacts on the use of electronic information resources, although, computer experience has a moderating effect on a student's intention to use electronic information resources.

\section{Interdependencies between the Identified Determinants}

There was a clear interdependency between the identified determinants that influence students' intention to use electronic information resources. The results indicated the relationship with the constructs namely, effort expectancy, facilitating conditions, behavioural intention and behaviour. This concludes that the isolation of these constructs from one another might not yield a complete idea in electronic information resources usage of postgraduate students at the EUSL.

\section{Recommendation and Contribution of the Study}

The study contributed to the existing literature that outlined how the UTAUT model can be used in assessing the students' use of electronic information resources. Further, the results of the research can be used for researchers in future as a literature support to study for electronic information resource usage. The final model can be adopted by other universities to analyze the students' behavioral intention to use electronic information resources. Moreover, the administrators can strategically plan before adopting any new technologies that are introduced within the institutions. The research suggests that the students' performance expectancy for electronic information usage might be increased by focusing on the usefulness of electronic resources and make resources available through modern technological systems. Further, the benefits and advantages of electronic resource services were demonstrated and promoted to the students in an interactive method. The educator and electronic resource provider should enhance the students' confidence, ability and self-esteem to use the technology. Giving activities and assignments related to the research methodology and literature review might change students' intention to use electronic information resources. In order to achieve the ultimate goal, the libraries need to improve their ICT infrastructure, Internet connections, quality of the website, human resources, technological support, and effective strategic plan could be included in the development such as policies, maintenance of hardware, software and databases, outsourcing and consultancy and training courses.

\section{Conclusion}

The study results indicate that postgraduate students are much aware of the electronic information resources and willing to adopt its utilization for their academic activities. The UTAUT research model shows the students' intention to use electronic information resource depending on facilitating conditions and effort expectancy only. 
In conclusion, the findings could be adapted to implement and improve the electronic information services to all higher education institutes in Sri Lanka and other countries globally as well.

\section{References}

Ajzen, I. (1991). The theory of planned behavior. Orgnizational Behavior and Human Decision Processes, 50(2), 179-211. Retrieved October 28, 2018, from https://doi.org/10.1016/0749-5978(91)90020-T

Al-Shafi, S., \& Weerakkody, V. (2009). Understanding Citizens' Behavioural Intention in the Adoption of E-Government Services in the State of Qatar. 17th European Conference on Information Systems UNDERSTA, (2009), 1-13. Retrieved June 30, 2018, from http://aisel.aisnet.org/ecis2009/185/

Awwad, M. S., \& Al-Majali, S. M. (2015). Electronic library services acceptance and use. The Electronic Library, 33(6), 1100-1120. Retrieved June 10, 2018, from http://dx.doi.org/10.1108/EL-03-2014-0057

Dilroshan, T. L. C. (1995). Identification of problems faced by university libraries in the process of automation : with special reference to the libraries of Moratuwa and Colombo Universities . History of Library Automation in Sri Lanka. Sri Lanka Journal of Librarianship and Information Management,1(2), 82-97. Retrieved August 12, 2018, fromhttp://dx.doi.org/10.4038/sllim.v1i2.434

Egberongbe, H. S. (2011). The Use and Impact of Electronic Resources at the University of Lagos, Library Philosophy and Practice (e-journal), 472. Retrieved October 22, 2018, from

http://digitalcommons.unl.edu/cgi/viewcontent.cgi?article=1490\&context=libp hilprac

He, D., Wu, D., Yue, Z., Fu, A., \& Vo, K. T. (2012). Undergraduate students interaction with online information resources in their academic tasks: A comparative study. Aslib Proceedings, 64(6), 615-640. Retrieved July 12, 2018, from https://doi.org/10.1108/00012531211281715

Ikart, E., \& Ikart, E. M. (2005). An Investigation of the Determinants of User Acceptance of Information Technology in a West African Nation : The Case of Nigeria. 16th Australasian Conference on Information Systems. Sydney (2005), 15. Retrieved June 18 2018, from https://pdfs.semanticscholar.org/d4ac/ecc1d541da741b8946632a8382ffb7c7c3 f8.pdf

Ingutia-oyieke, L., \& Dick, A. L. (n.d.). A comparative analysis of the use of electronic resources by undergraduate students at two kenyan universities, 28(2), 64-81. Retrieved January 282019, from http://repository.up.ac.za/bitstream/handle/2263/16191/Ingutia-

Oyieke_Comparative(2010).pdf?sequence=1

Kalema, B. M., \& Kekwaletswe, R. a Y. M. (2011). The Application of Structural Equation Modeling Technique to Analyze Students Priorities in Using Course Management Systems. International Journal of Computing and ICT Research, 5(December), 34-44. Retrieved July 21, 2018 from http://ijcir.org/specialissue2011/article5.pdf

Karunarathna, H. M. P. P. (2015). Use of Electronic Resources by Law Degree Students at Anuradhapura Regional Centre of the Open University of Sri Lanka. 
Journal of the University Librarians Association of Sri Lanka, 18(2), 41-61. Retrieved April 11, 2018 from https://doi.org/10.4038/jula.v18i2.7865

Kaur, B., \& Verma, R. (2009). Use and impact of electronic journals in the Indian Institute of Technology, Delhi, India. The Electronic Library, 27(4), 611-622. Retrieved August 21, 2018 from https://doi.org/10.1108/02640470910979570

Li, L. (2010). A critical review of technology acceptance literature. [A Critical Review of information systems]. Southwest Decision Sciences Institute. Retrieved May 23, 2018 from http://www.swdsi.org/swdsi2010/SW2010_Preceedings/papers/PA104.pdf

Marchewka, J. T., \& Kostiwa, K. (2007). An Application of the UTAUT Model for Understanding Student Perceptions Using Course Management Software. Communications of the IIMA, 7(2), 93-104. Retrieved December 21, 2018 from http://scholar.google.com/scholar?hl=en\&btnG=Search\&q=intitle:An+Applica tion+of+the+UTAUT+Model+for+Understanding+Student+Perceptions+Usin $\mathrm{g}+$ Course+Management+Software\#0

Margaret, M \& Mabawonku, I. (2013). Information Retrieval Skills and Use of Library Electronic Resources by University Undergraduates in Nigeria. Information and Knowledge Management, 3(9), 6-15.Retrieved December 11, 2018 from https://pdfs.semanticscholar.org/67f2/a4c62986b37713b68150229a9a3110cf6 daf.pdf

Millawithanachchi, U. S. (2009). An Investigation of Critical Success Factors on EResource Based Learning: a case study based on the electronic information resources available at the University of Colombo .Master thesis, University of Colombo, Sri Lanka.

Millawithanachchi, U. S., \& Jayasundara, C. C. (n.d.). Critical Success Factors on EResource Based Learning: a case study. Master Thesis, FGS, University of Colombo, Sri Lanka. Retrieved march 27, 2018 from http://archive.cmb.ac.lk:8080/research/handle/70130/166

Peris, N. . \& P. B. . (2012). Use of Electronic Information Resources by postgraduate students : a case study. Journal of the University Librarians Association, 16, 46-69.Retrieved May 30, 2018 from

https://jula.sljol.info/article/10.4038/jula.v18i2.7865/galley/5200/download/

Punchihewa, C. N. D. (2008). Usage of Online Databases and User Perceptions Towards the Facilities Provided: a case study at University of Moratuwa. Master Thesis, FGS, University of Colombo, sri Lanka. Retrieved August 23 2018 from

http://archive.cmb.ac.lk/research/bitstream/70130/3891/1/MLS004.pdf

Quadri, G. O. (2012). Impact of ICT Skills on the Use of E-Resources by Information Professionals: A Review of Related Literature, Library Philosophy and Practice (e-journal), 762. Retrieved July 242018 from http://digitalcommons.unl.edu/cgi/viewcontent.cgi?article=1836\&context=libp hilprac

Raman, A., Don, Y., Khalid, R., \& Rizuan, M. (2014). Usage of learning management system (Moodle) among postgraduate students: UTAUT model. Asian Social Science, 10(14), 186-192. Retrieved June 142018 from 
https://doi.org/10.5539/ass.v10n14p186

Ramolapremalatha, J. (2016). Applicability of Unified Theory of Acceptance and Use of Technology in Indian Context - A review. International Journal of Marketing, Financial Services \& Management Research, 5(3), 3-6.Retrieved July 242018 from

http://indianresearchjournals.com/pdf/IJMFSMR/2016/February/4.pdf

Rehman, S. U. (2012). Perceptions of Pakistani Users about Library Service Quality : LibQUAL Comments Use of Library Information Technology Resources by Graduate Students of University of Agriculture, Abeokuta. Library Philosophy and Practice(e-journal). 710. Retrieved January 212019 from http://digitalcommons.unl.edu/libphilprac/710/

Samaradiwakara, M. N. (2014). Comparison of Existing Technology Acceptance Theories and Models To Suggest a Well Improved Theory/Model. International Technical Sciences Journal, 1(1), 21-36. Retrieved from March 62019 from http://elpjournal.eu/wp-content/uploads/2016/03/itsj-spec-1-1-3.pdf

Samaradiwakara, M. N. (2014). Use and acceptance of information and communication technologies (ICTs) by university students: developing a model for the sri lankan context .PhD thesis, University of Colombo, Sri Lanka.

Tao, D. (2008). Understanding Intention to Use Electronic Information Resources: A Theoretical Extension of the Technology Acceptance Model (TAM). AMIA Annual Symposium Proceedings, 2008, 717-721. Retrieved March 13, 2019from

http://www.ncbi.nlm.nih.gov/pmc/articles/PMC2656102/\%5Cnhttp://www.nc bi.nlm.nih.gov/pmc/articles/PMC2656102/pdf/amia-0717-s2008.pdf

Tibenderana, P. K. G. (2008). Acceptance and use of electronic library services in Ugandan universities, Proceedings of the 8th ACM/IEEE-CS Joint Conference on Digital Libraries - JCDL 2008, 323-332. Retrieved May 212018 from https://dl.acm.org/citation.cfm?id=1378944

Venkatesh, V., Morris, M. G., Davis, G. B., \& Davis, F. D. (2003). User Acceptance of Information Technology. MIS Quarterly, 27(3), 425-478. Retrieved December 222018 from https://doi.org/10.1006/imms.1993.1022

Wu, M., \& Chen, S. (2012). How graduate students perceive, use, and manage electronic resources. Aslib Proceedings, 64(6), 641-652. Retrieved December 12, 2018 from https://doi.org/http://dx.doi.org/10.1108/00012531211281779

Wu, Y. L., Tao, Y. H., \& Yang, P. C. (2007). Using UTAUT to explore the behavior of 3G mobile communication users. IEEM 2007: 2007 IEEE International Conference on Industrial Engineering and Engineering Management, 199-203. Retrieved December 12, 2018. from https://doi.org/10.1109/IEEM.2007.4419179 